\title{
Factors that affect the spatial and temporal distribution of nitrate in a free aquifer of an agricultural plain basin
}

\author{
Carolina Calvi $^{1}$ (i) $\cdot$ Cristina Dapeña ${ }^{1} \cdot$ Daniel E. Martinez ${ }^{2}$
}

Received: 14 February 2020 / Accepted: 29 August 2020

(c) Springer-Verlag GmbH Germany, part of Springer Nature 2020

\begin{abstract}
The behavior of nitrate in shallow aquifers depends on several factors, such as geomorphology, soil type, thickness of the vadose zone, and its lithology, sampling period, among others. In the free aquifer of the basin of the La Ballenera creek in southeastern of Buenos Aires province, Argentina, nitrate varies in a range between 4 and $250 \mathrm{mg} / \mathrm{L}$ in samples taken in spring and winter. This basin has a large agricultural production where fertilizers are applied, and nitrates come from them. Statistical analysis of the data allow to make conclusion about the main factors that influence the variation of the nitrate content in aquifers, in this case are the lithology and the thickness of the vadose zone, related to the different transit times. The results obtained can be extrapolated to analogous basins, considering that in the spatial analysis of nitrates the heterogeneities of the system should be considered. The importance of characterizing a system with more than one sampling at several sufficiently spaced times is emphasized.
\end{abstract}

Keywords Groundwater · Vadose zone $\cdot$ Soil · Geomorphology $\cdot$ Natural background · Contamination

\section{Introduction}

Elevated nitrate concentrations in groundwater are undesirable and it has become an important environmental indicator of human impact (Edmunds and Shand 2008; Sutton et al. 2011; Liu et al. 2015; Kim et al. 2015). The nitrate contamination of groundwater can cause risks to human health and the environment (L'hirondel and L'hirondel 2001; Powlson et al. 2008). The World Health Organization (WHO 2011) has set the threshold of $50 \mathrm{mg} / \mathrm{L}$ as $\mathrm{NO}_{3}{ }^{-}$for drinking water. Excess nitrate leads to methaemoglobinaemia (blue-baby syndrome) in infants less than 6 months old. Furthermore,

This article is a part of the Topical Collection in Environmental Earth Sciences on "Advances in Environmental Geochemistry" guest edited by Dr. Eleanor Carol, Dr. Lucia Santucci and Dr. Lia Botto.

\section{Carolina Calvi}

calvi@ingeis.uba.ar

1 Instituto de Geocronología y Geología Isotópica (INGEIS, CONICET-UBA), Pabellón INGEIS, Ciudad Universitaria, 1428 Buenos Aires, Argentina

2 CONICET e Instituto de Geología de Costas y del Cuaternario (CGCyC)-UNMDP, CC 722, 7600 Mar del Plata, Argentina it can pose health problems to pregnant women and gastric troubles in older adult, among other diseases (L'hirondel and L'hirondel 2001). Other researchers argue that there are other critical factors than the nitrate content in drinking water (Fewtrell 2004; Manassaram et al. 2010).

The natural background range and the threshold allow identified anomalous $\mathrm{NO}_{3}$ concentrations in groundwater (Panno et al. 2006; Masetti et al. 2008; Giuliano Albo and Blarasin 2014; Cruz and Andrade 2015). Several researchers have indicated a relationship between agriculture and high nitrate concentration in groundwater (Jordan and Smith 2005; Liu et al. 2005; Burkart and Stoner 2008; Sutton et al. 2011, Wheeler et al. 2015; Amano et al. 2016; Valujeva 2016). Nitrate is the most stable of the inorganic nitrogen compounds in aerobic environments and is highly leachable through the soil profile into aquifers (Picone et al. 2003; Almasri 2007; Buczko et al. 2010; Baram et al. 2014). This is linked to low retardation coefficient relative to groundwater flow, low chemical degradation and diffuse continue character over time of the main sources of pollution (Foster et al. 2002; Chowdary et al. 2005; Rivett et al. 2006).

The content of nitrate in agro-ecosystems aquifers is affected by several factors: type, intensity and frequency of agricultural activities, soil type, climate variability, thickness and lithology of the vadose zone (VZ), and the own 
aquifer characteristics (Óenema et al. 1998; Hudak 2000; Lake et al. 2003; Muñoz et al. 2004; Rimski-Korsakov et al. 2004; Andrade and Stigter 2009; Brenes et al. 2011; Giuliano Albo and Blarasin 2014; Woli et al. 2016).

The main goal is studied the factors which contribute to the occurrence of high nitrate concentration in a typical agricultural catchment in humid plain area.

\section{Study area}

The study area is part of the Wet Pampa Plain and belongs to the geographical region Interserrana Plain which is extended between Tandilia and Ventania mountain ranges in the Buenos Aires Province (Argentina). La Ballenera is a small basin of $160.13 \mathrm{Km}^{2}$ with low slope around $0.6 \%$ (Calvi et al. 2016a) and orientation $\mathrm{N}-\mathrm{S}$ perpendicular to the coastline. This stream flows from the Tandilia system to the Argentine Sea, but before that it feed La Ballenera pond near to the outlet (Fig. 1).The main towns in the catchment are Miramar and Comandante Nicanor Otamendi with 30,000 and 7000 inhabitants, respectively.

The climate has a "moderate-humid" climate (Köppen's classification) or "sub humid-humid, mesothermal, without water deficiency" type (Thornthwaite's method) (Thornthwaite 1948) with a mean annual temperature of $13.5^{\circ} \mathrm{C}$ (CHEM 2013). In the period 1971-2015, the average annual rainfall in the catchment is $900 \mathrm{~mm}$, and the average monthly rainfall is $74.9 \mathrm{~mm}$ (Calvi et al. 2014). Low slopes feature allows vertical processes, i.e., evaporation and infiltration to become dominant (Calvi et al. 2016a). During autumn-winter, the precipitation broadly exceeds the evapotranspiration generating an excess which mainly corresponds to infiltration (Calvi and Martinez 2018). The dominant vegetation was originally the grass steppe (Mosciaro and Dimuro
2009), but the region has been greatly altered by human activities, such as livestock and agriculture. At present the intensive agriculture is the major economic activity, mainly the crops of wheat, barley, maize, sunflower, soybean, and potato cultivation (Huarte and Capezio 2013).

\section{Geology and hydrogeology setting}

Several researchers have studied the regional geological and hydrogeological characteristics in the area (Sala 1975; Sala et al. 1983; Kruse 1986 and González 2005). The hydrogeological basement is included in "Complejo Buenos Aires" and "Balcarce" Formations. The multi-layered phreaticsemiconfined aquifer sequence is contained by layers of loess-like silt and silty-sand with precipitated $\mathrm{CaCO}_{3}$ called "Pampean sediments" (Fig. 2). The mineralogical composition of these sediments was described by Teruggi (1954) and Martinez and Osterrieth (2013), and is mainly formed by quartz, plagioclases, and orthoclase with variable amounts of volcanic glass shards. The thickness of these Quaternary deposits varies between 30 and $100 \mathrm{~m}$ (Fig. 2) with typical hydraulic conductivity $10 \mathrm{~m} / \mathrm{d}$ (Sala 1975), porosity of $15 \%$ and transmissivity around $800-1000 \mathrm{~m}^{2} / \mathrm{d}$. The groundwater is sodium bicarbonate type with $\mathrm{pH}$ around 7.3 (Calvi et al. 2016b).

\section{Characteristics of geomorphology and soils}

The study area is classified into two main morphodynamic units: system of hills and plain system plus shorelines (Calvi et al. 2016a). The first one has slopes from 1.71 to $15.8 \%$ and is formed by silt and silt-sandy composition sediments, with frequent calcretes (locally called tosca) interbedded (Fig. 1).
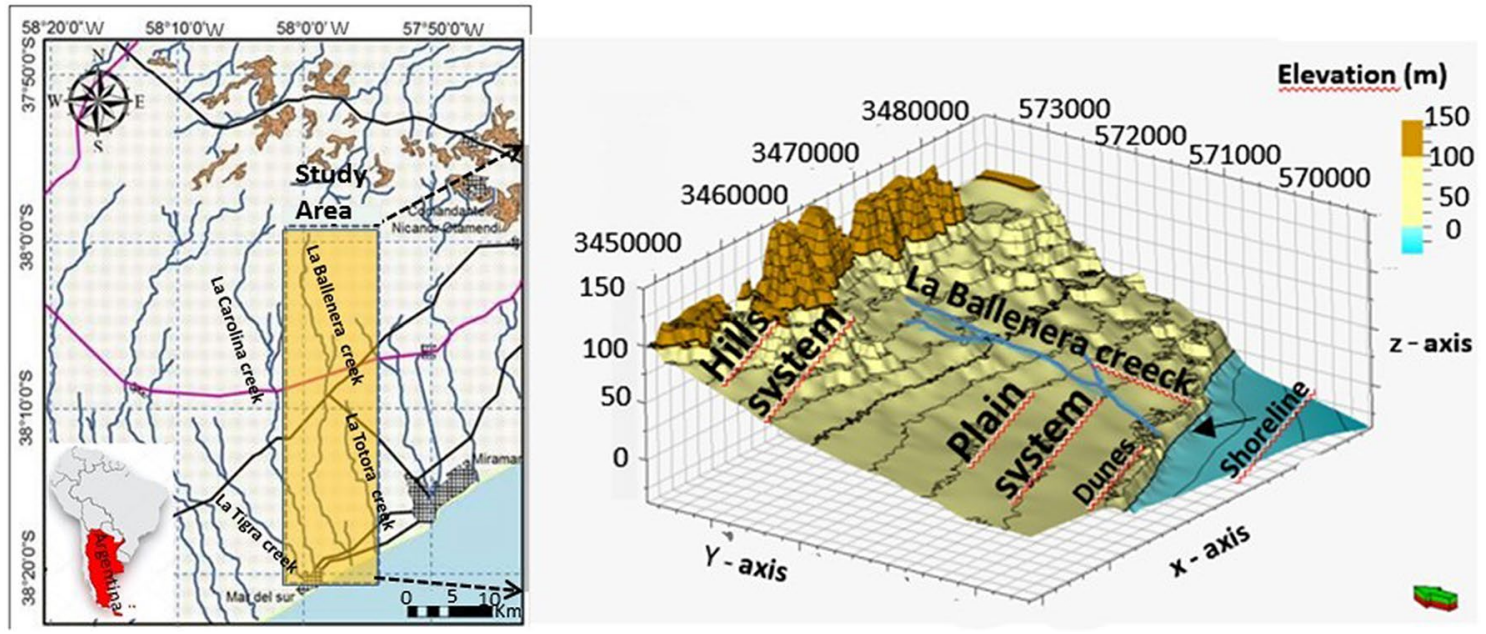

Fig. 1 Location map of the study area and 3D view of La Ballenera catchment 


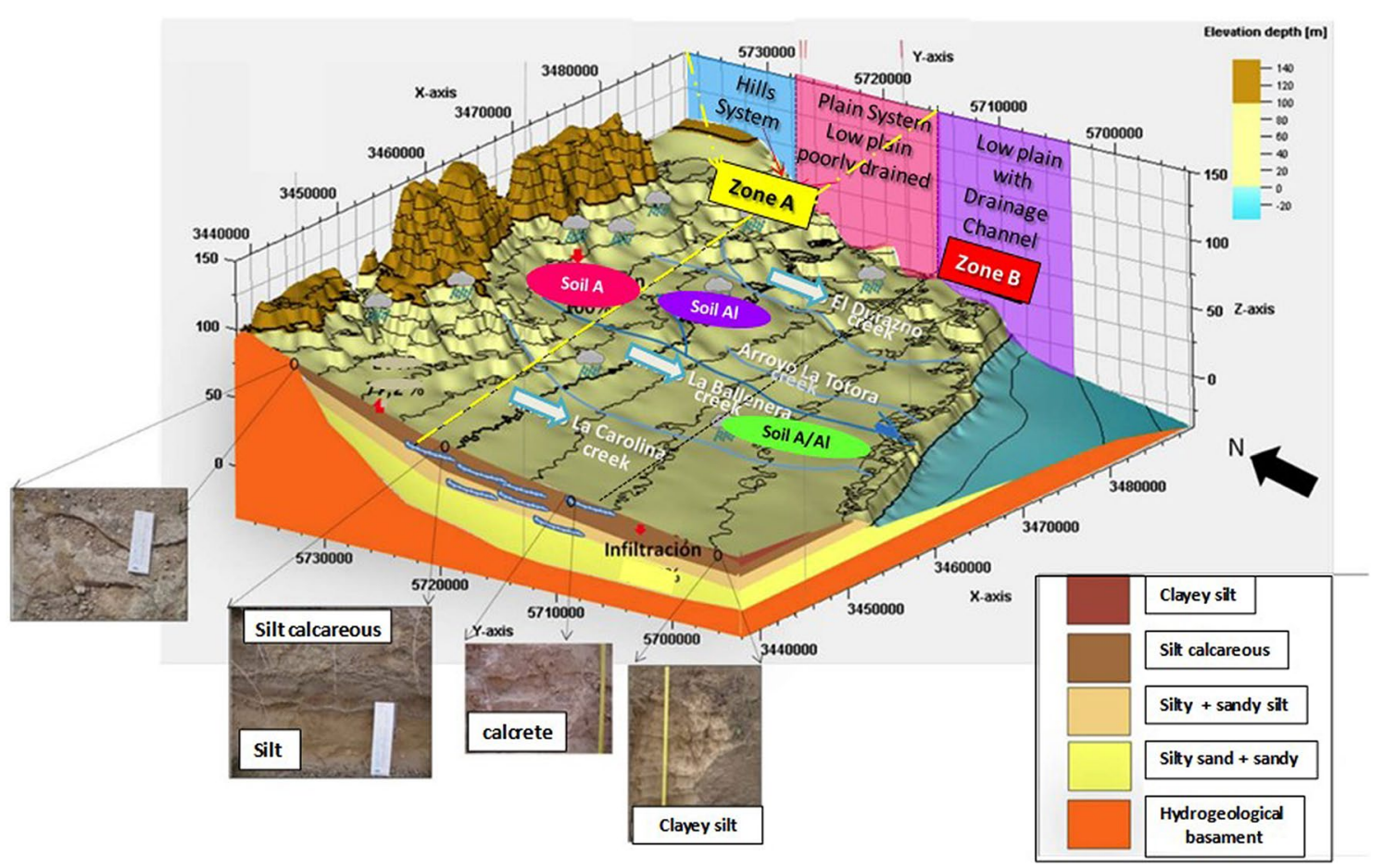

Fig. 2 Diagram block showing geomorphology and geology of the study area

The second one represents the largest plain in the basin and comprises a plain area slopes lower than $1.7 \%$ and a band of dunes next to the shoreline. The composition of this system is silt, silt-claying, and silt-sandy (Fig. 1) and two geomorphological units are distinguished: the poorly drained low plain (zone A) and the drainage drained low plain (zone B) (Fig. 2). The vertical hydrologic (infiltration and evaporation) are the dominant processes owing most of the basin has low slopes.

In the Interserrana area the predominant soils belong to the Mollisol Order (INTA 1989, 2011). These soils are the result of the action of a humid climate on loessic materials. At the head of the La Ballenera catchment, with slopes over 5.2\%, of the dominant order is Argiudolls (A), with several subgroups of which the most important are the typical Argiudolls and Pretrocalcic Argiudolls (Fig. 2). The Argiacuolls soils ( $\mathrm{Al})$ are the main soils in the middle part of the basin with slopes lower than $5.2 \%$. The soils next to the shoreline with low slopes of about $1.7 \%$ are Argiudolls and Argiacuolls (A and Al) (Fig. 2). These soils have $5-7 \%$ organic matter and $25-26 \%$ clay in the surface horizon (Costa 1999; Suero et al. 2002).

The main problems affecting these soils are sodium excess, impeded drainage, and high $\mathrm{pH}$. However, the soils are generally well developed and widely distributed. They have dark colors and high contents of organic matter and nutrients. Those characteristics define them as the most fertile soil in the country (Álvarez et al. 2008).
In La Ballenera catchment, the natural background range statistically calculated is $4-11 \mathrm{mg} / \mathrm{L}$ (Calvi et al. 2018). The values above the threshold of nitrate calculated for the whole basin $(>11 \mathrm{mg} / \mathrm{L})$ are related to agricultural activities introducing nitrogen in fertilizers and promoting the nitrate leaching which causes groundwater contamination.

\section{Methodology}

The sampling network for nitrate analyses consisted of 75 wells along La Ballenera catchment. These groundwater samples were taken on shallow windmill boreholes about $25 \mathrm{~m}$ depth, and irrigation wells about $50 \mathrm{~m}$ depth. A first groundwater sampling campaign for chemical analysis was carried out during October-November 2013 (spring season), when fertilization was being done. A second sampling campaign was followed up during July 2014 (winter season) without fertilization.

All sampling points were located by Global Positioning System (GPS) Garmin eTrex Vista for later use in maps and graphics. Also, water depth below surface level was measured in 56 wells, using a bipolar electric probe. The Geographic Information System (GIS) ArcGis 10.1 (ESRI 2012) was used to draw the piezometric lines and equal thickness maps. To achieve the objective, nitrate distribution maps were analyzed along the catchment in spring and winter campaigns. Nitrate analyzes were done by UV spectrometry 
in the Hydrochemistry and Isotope Laboratory of the Hydrogeology Group (University of Mar del Plata). The detection limit was $0.1 \mathrm{mg} / \mathrm{L}$ and the mean error was $1 \%$.

\section{Statistical analysis}

The nitrate distribution was analyzed in relation to several factors as geomorphology, sampling depth (25 or $50 \mathrm{~m}$ ), type of soils, thickness of VZ, and spring or winter crops. Some statistical parameters were obtained: mean nitrate concentration, standard error; standard deviation; number of analyses with nitrate concentrations higher than $50 \mathrm{mg} / \mathrm{L}$ with respect to the total number of samples and its percentage.

In addition, the box plots were performed to compare the medians of nitrate concentration between winter and spring sampling campaigns respect to the factor most representative. Finally, a diagram of $\mathrm{NO}_{3}$ and $\mathrm{VZ}$, was analyses according to the outcrop $\mathrm{N}-\mathrm{S}$ of the catchment.

\section{Results}

\section{Groundwater affected by nitrate}

The nitrate distribution was analyzed according to the variables of geomorphology, sampling depth, type of soils, thickness of VZ, and seasons (spring or winter samples) (Table 1). The threshold $50 \mathrm{mg} / \mathrm{L}$ of nitrate is exceeded mostly to the geomorphologic plain area (zone B; $54.5 \%$ of samples) with average values of $83.4 \pm 7.6 \mathrm{mg} / \mathrm{L}$. Water is considered nondrinking when it has more than $50 \mathrm{mg} / \mathrm{L}$ nitrate, from the WHO regulations.

Respecting to the relationship among concentration and sampling depth, the first $25 \mathrm{~m}$ (windmills; mean of $64.5 \pm 9.5 \mathrm{mg} / \mathrm{L}$ ) show $57.5 \%$ of the samples that exceed threshold set by WHO (Table 1). The highest concentrations were detected in $\mathrm{A} / \mathrm{Al}$ and $\mathrm{Al}$ soil type which have $83.2 \pm 7.0 \mathrm{mg} / \mathrm{L}$ y $63.4 \pm 8.8 \mathrm{mg} / \mathrm{L}$ nitrate, respectively, with 50.0 and $52.9 \%$ of samples exceeding $50 \mathrm{mg} / \mathrm{L}$. Samples located in VZ with thickness $<2 \mathrm{~m}$ have a mean of $90 \pm 7.2 \mathrm{mg} / \mathrm{L}$ and this value belong to zone $\mathrm{B}$ of the plain area, where $60 \%$ of samples exceed the limit established by WHO (Table 1). Finally, the spring and winter sampling campaigns have a similar nitrate concentration (Table 1).

The previous data show that the VZ is the most sensitivity variable responsible of nitrate content $(60 \%$ of samples $>50 \mathrm{mg} / \mathrm{L}$; Table 1). To demonstrate this result, box plots are performed to compare in both samplings campaigns the medians of nitrate concentration respect to VZ thickness. Also, Fig. 3 shows the thickness of VZ in the basin. The highest nitrate concentration is found in $\mathrm{VZ}<2 \mathrm{~m}$ during spring. However, $\mathrm{VZ}$ from 2 to $6 \mathrm{~m}$ has higher nitrate concentration in winter than in spring (Fig. 3a).

In addition, Fig. 4 represents a dispersion plot of VZ thickness vs. nitrate content differentiating spring and winter samplings. In $\mathrm{VZ}<2 \mathrm{~m}$ where the lithology is mainly silt, Fig. 4 shows that high nitrate concentration are grouped in spring sampling and low nitrate concentration are clustered in winter sampling. However, VZ 2-12 $\mathrm{m}$ is formed by thick calcrete bank and hardy silt with carbonate content, showing different behavior in the spring and winter nitrate value (Fig. 4). The lithology of VZ>12 m is silt and calcrete, in spring and winter sampling exhibit low nitrate concentration.

The nitrate concentration was analyzed in space and time along the catchment through 3D diagrams and maps (Figs. 5 and 6). The highest concentration of nitrate is next to the discharge in October (spring) (Fig. 5). However, the highest values in winter (July) are in the middle of the basin (Fig. 6).
Table 1 Mean Nitrate (mg/L); Standard Error (SE); Standard Deviation (SD); Number of analyses in spring with $\mathrm{NO}_{3}>50 \mathrm{mg} / \mathrm{L}$ respect to the total samples (Num); $\cong \%$ of samples with $\mathrm{NO}_{3}>50 \mathrm{mg} / \mathrm{L}$

\begin{tabular}{lllrrrr}
\hline Variable & Subcategory & Mean & SE & SD & Num. & $\%$ \\
\hline Geomorphology & Zone A $(n=53)$ & 51.6 & 10.0 & 2.7 & $23 / 53$ & 43.4 \\
& Zone B $(n=22)$ & 83.4 & 7.6 & 2.9 & $12 / 22$ & 54.5 \\
Death & $\sim 25 \mathrm{~m}(n=48)$ & 64.5 & 9.5 & 2.7 & $22 / 48$ & 57.5 \\
\multirow{3}{*}{ Type of soils } & $\sim 50 \mathrm{~m}(n=27)$ & 54.5 & 7.8 & 2.6 & $12 / 27$ & 44.4 \\
& A $(n=22)$ & 39.9 & 9.1 & 2.8 & $7 / 22$ & 22.5 \\
& Al $(n=36)$ & 63.4 & 8.8 & 2.8 & $16 / 36$ & 50.0 \\
VZ & A/Al $(n=17)$ & 83.2 & 7.0 & 2.8 & $9 / 17$ & 52.9 \\
& $<2(n=20)$ & 89.6 & 7.2 & 2.7 & $12 / 20$ & 60.0 \\
& 2-6 $(n=321)$ & 56.2 & 8.4 & 2.8 & $12 / 31$ & 38.7 \\
Samples & $>6(n=24)$ & 44.6 & 7.5 & 2.7 & $9 / 24$ & 47.8 \\
& Spring $(n=34)$ & 60.4 & 8.6 & 2.7 & $12 / 34$ & 35.3 \\
& Winter $(n=41)$ & 61.4 & 9.2 & 2.8 & $19 / 41$ & 46.3 \\
\hline
\end{tabular}



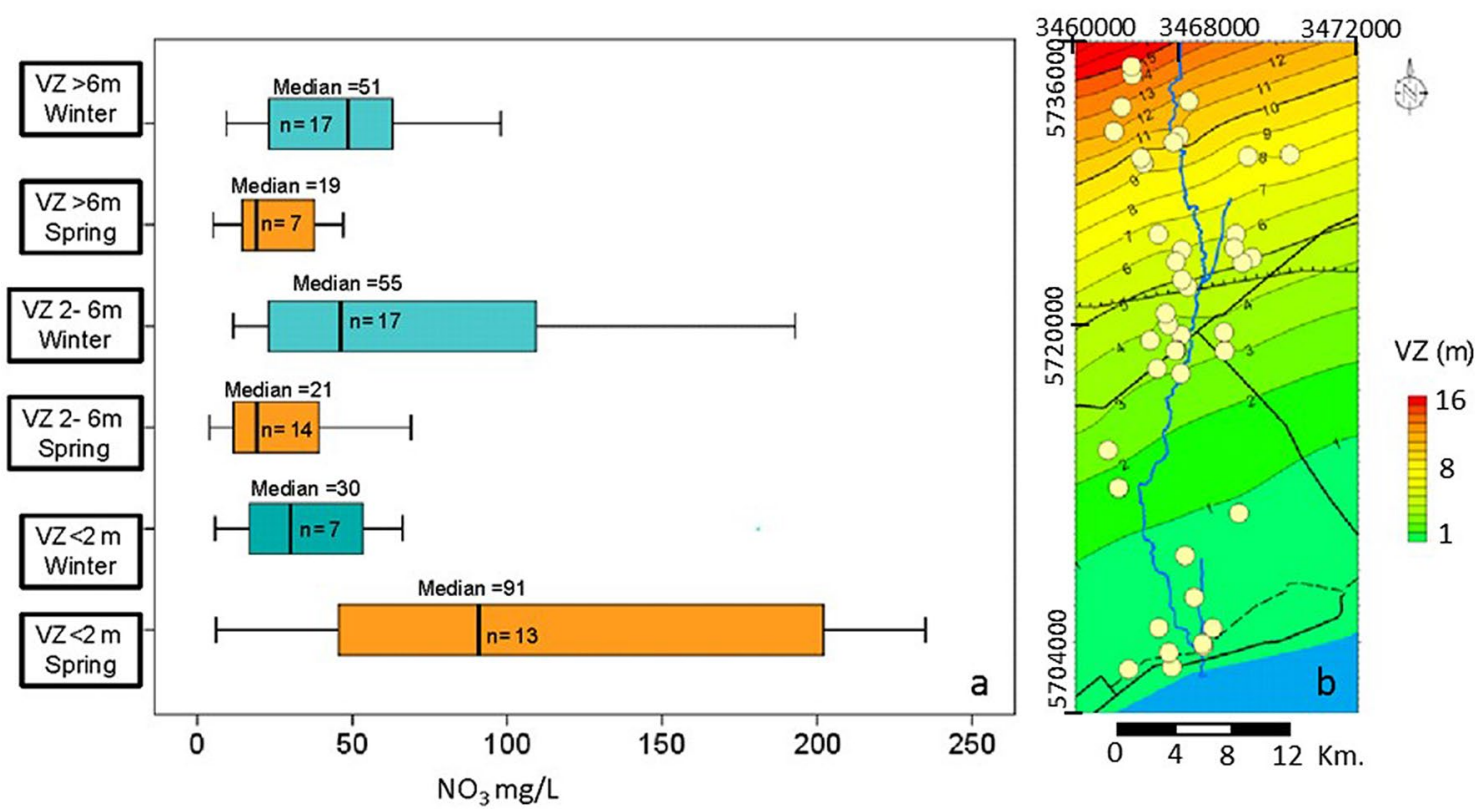

Fig. 3 a Box plots showing the distribution of groundwater nitrate concentration for different thickness classes of vadose zone; b Vadose zone thickness map

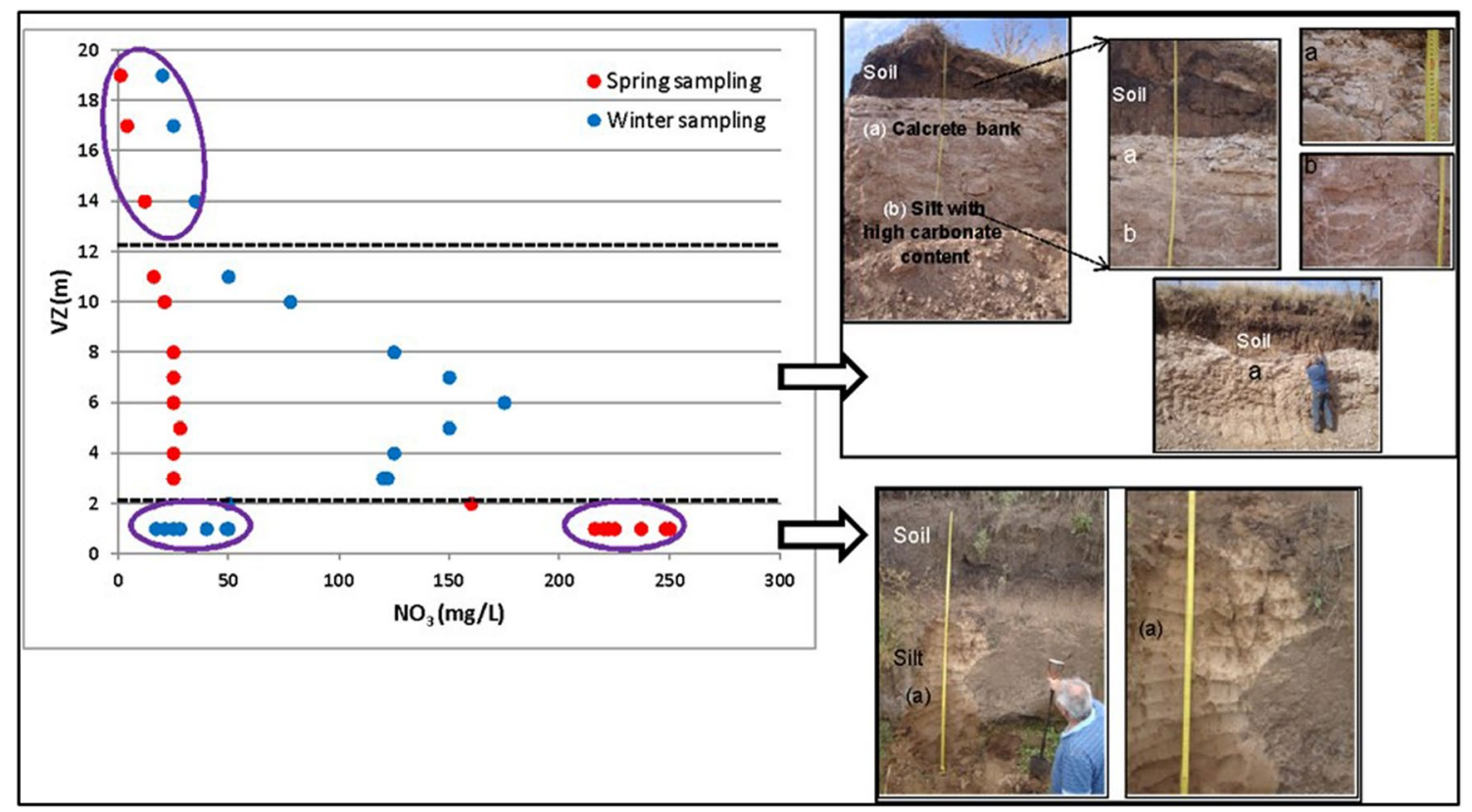

Fig. 4 Left: dispersion diagram N-S catchment between VZ and concentration of spring and winter sampling. Right: outcrops of the VZ 0-2 m and 2-12

\section{Discussion}

The high concentrations of nitrate observed (up to $250 \mathrm{mg} / \mathrm{L}$ ) usually are related to agricultural activities as in other areas of the Pampean plain (Costa et al. 2002, 2011 among others) and the world (Follett and Hatfield, 2001; Wick et al. 2012; Hansen et al. 2016, 2017; Lawniczak et al. 2016; Qasemi et al. 2018; Kawagoshi et al. 2019). The addition of nitrogen fertilizer in crops, particularly in vegetables (potatoes, carrots, and beets) and wheat and barley (Echeverría and Ferrari 1993; Barbieri et al. 2009) 


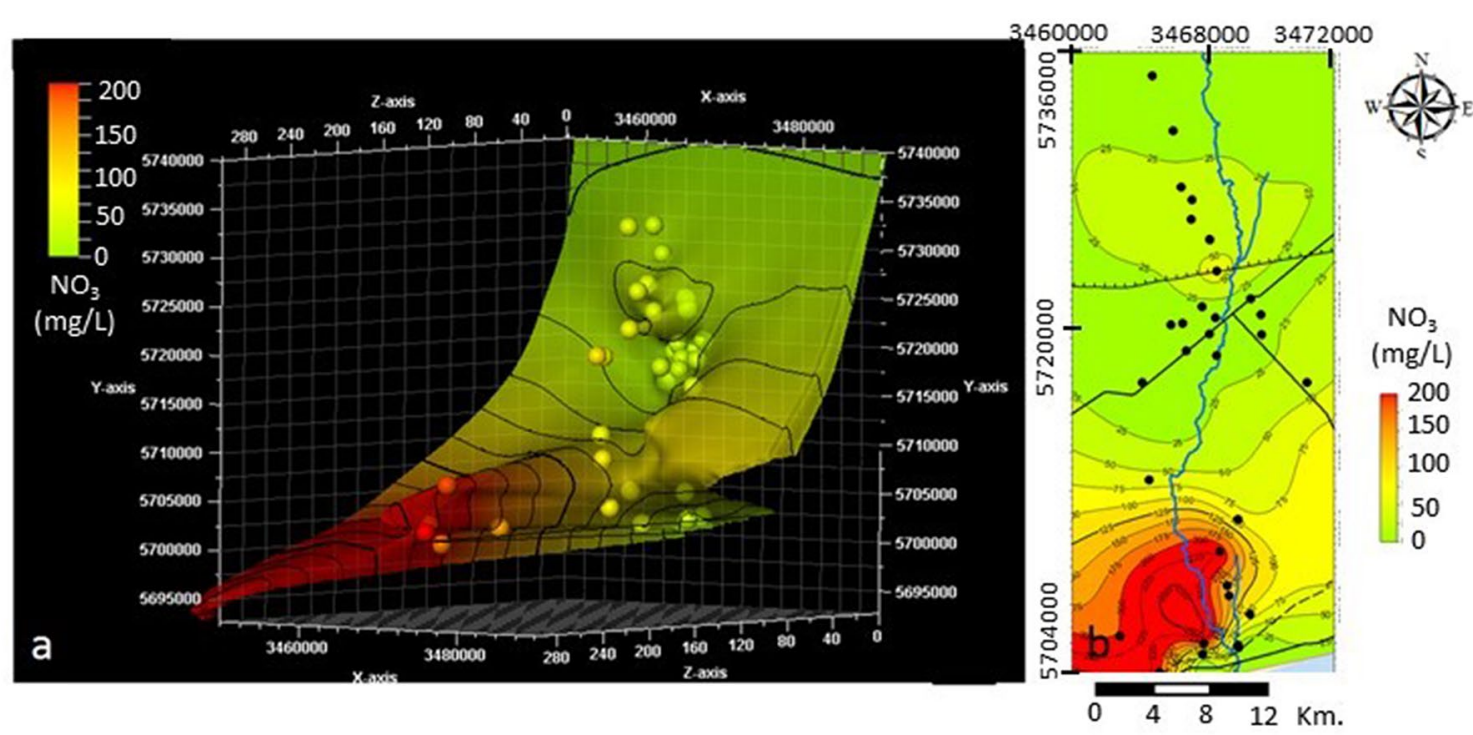

Fig. 5 Nitrate concentration: a Representation 3D in Spring (October); b Map of isoconcentration in Spring (October)
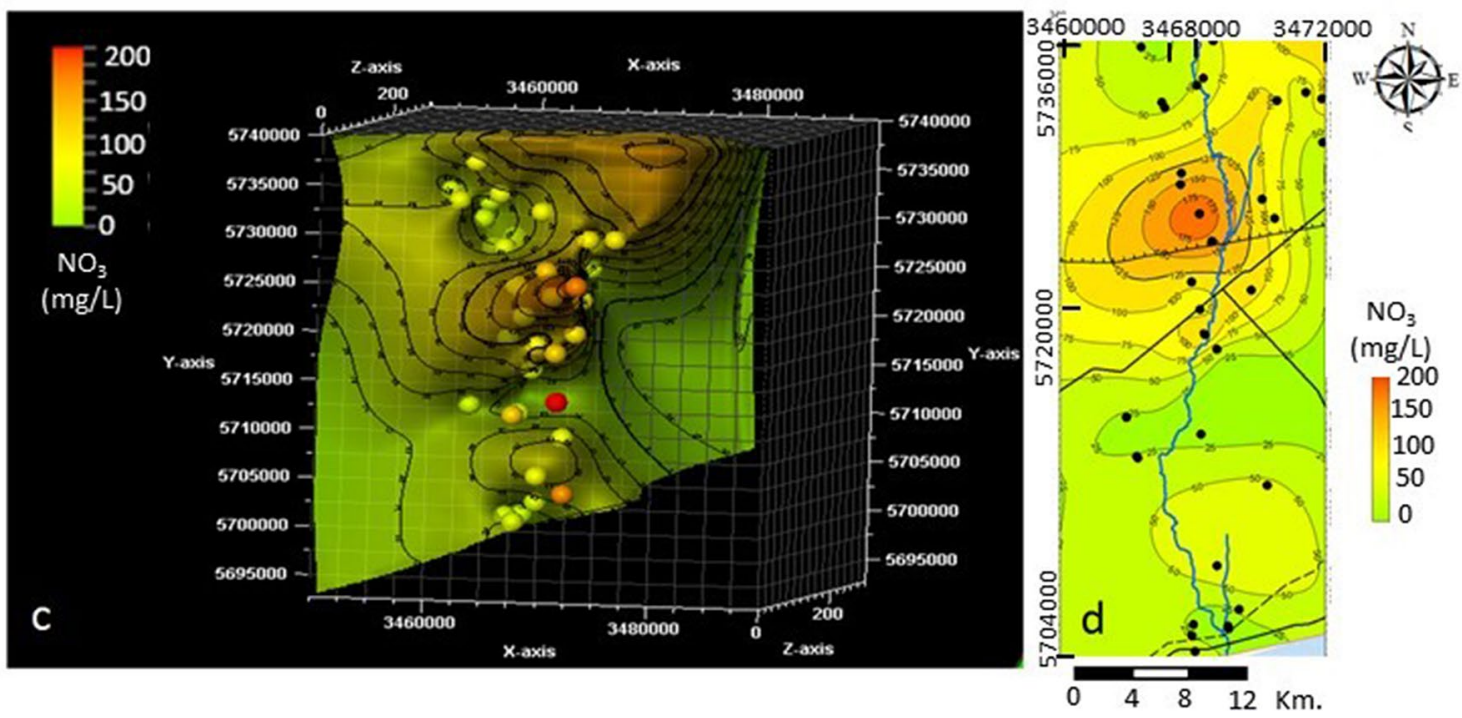

Fig. 6 Nitrate concentration: c Representation 3D in Winter (July). d Map of isoconcentration in Winter (July)

causes groundwater contamination. In the study zone, the period of fertilization goes from September to December when the probability of leaching is much lower because infiltration rates are lesser (evapotranspiration greater than precipitation). Nitrate leaching occurs when the soil is saturated with water and nitrate is washed beyond the root zone by percolating rainfall or irrigation.

The thickness and lithology of VZ are parameters that mainly impinge on ground water vulnerability (Foster 1987; Blarasin et al. 2003; Fenton et al. 2009; Liu et al. 2015; among others). In the Ballenera basin, the zone A has the highest VZ thickness (mean: $8.5 \mathrm{~m}$ ) and the lithology is composed by soil, silt, and discontinuous calcretes levels (Figs. 2 and 3). As well, the thickest calcrete bank was observed in the range of VZ 2-12 $\mathrm{m}$ and it has a moderate to high nitrate concentration in winter and lesser in spring.

In contrast, in the plain area with ponds (zone B) in the distal part of the basin, the thinner VZ (less than $2 \mathrm{~m}$, Fig. 3b) has more sandy soils near coastal dunes and it has higher nitrate concentration in spring and lower in winter. Therefore, the nitrate concentration has opposite behavior during fertilized season (spring) and not fertilized season 
(winter) (Figs. 5 and 6). This result is linked to the different transit time in the VZ, which is lower in B than in A (mainly VZ 2-12 m), due to the lower thickness and lithology type (Fig. 4). As consequence, the nitrate value measured in Zone B is the result of the spring fertilization where the transport is dispersive. Whereas in zone A the nitrate applied in spring is measured in the next winter, showing successive pulses according to a piston flow model. Calvi and Martinez (2018) explained that the contrast in the isotopic composition of groundwater of these zones is consistent with the thickness and lithology type of both VZ related to different transit time. The hydrological balance confirms this assessment. The water excess calculated in winter (July 2014) allows the nitrate to be washed in the less thick area (zone B). The opposite occurred in spring (October 2013) due to the water deficit (Calvi et al. 2018).

These results show that performing nitrate concentration maps with a single sampling or two samplings separated by short times could be not adequate to show a realistic situation, because the arrival of nitrate to the upper water table can be driven by different mechanisms depending on the thickness of the VZ and the lithology. In the case of La Ballenera basin, where fertilization is applied in spring, it has been observed that for a sampling date it is possible to notice differences in concentrations in the low VZ area where a direct and recent impact is observed, against to the high VZ thickness where a continue and homogenized concentration is arriving.

\section{Conclusions}

The magnitude of nitrate leaching in the La Ballenera Catchment is influenced by geomorphology, type of soils, vadose zone thickness and its lithology, sampling season, among others, being lithology, and thickness of the VZ the main factors. It was determined applying a comparison of statistical analyzes and observing a map of the nitrate area from winter to spring samplings.

The results show different transit time and transport processes of the nitrate percolating from spring fertilization in vadose zone with variable thickness and lithology. Thus, it is necessary, on a side, to perform more than a sampling campaign to analyses the concentration of nitrate in phreatic aquifers. On the other side, it is demonstrated that analyzing all together the samples taken into a similar sampling period, the resulting distribution is not certainly consequence of the same fertilizer application season. The analysis of nitrate levels in an entire basin is a good practice if the heterogeneity of systems is also considered.

\section{References}

Almasri MN (2007) Nitrate pollution of groundwater: a conceptual management framework. Environ Impact Assess Rev 27:220-242

Álvarez MF, Osterrieth ML, Bernava Laborde V, Montti L (2008) Estabilidad, morfología y rugosidad de agregados de Argiudoles Típicos sometidos a distintos usos: su rol como indicadores de la calidad física de suelos de la provincia de Buenos Aires, Argentina. Ciencia del Suelo 26(2):115-129

Amano H, Nakagawa K, Berndtsson R (2016) Groundwater geochemistry of a nitrate-contaminated agricultural site. Environ Earth Sci 75:1145. https://doi.org/10.1007/s12665-016-5968-8

Andrade AIASS, Stigter TY (2009) Multi-method assessment of nitrate and pesticide pollution in shallow alluvial groundwater as a function of hydrogeological setting and land use. Agric Water Manag 96:1751-1765

Baram S, Kurtzman D, Ronen Z, Peeters A, Dahan O (2014) Assessing the impact of dairy waste lagoons on groundwater quality using a spatial analysis of vadose zone and groundwater information in a coastal phreatic aquifer. J Environ Manage 132:135-144

Barbieri PA, Echeverría HE, Sainz Rozas HR (2009) Nitratos en el suelo a la siembra o al macollaje como diagnóstico de la nutrición nitrogenada en trigo en el Sudeste Bonaerense. Ciencia del Suelo 27(1):41-47

Blarasin M, Cabrera A, Matteoda E (2003) Groundwater geoindicators for assessment of environmental changes, planning and policy implications, Río Cuarto, Argentia. J Environ Hydrol. 11:16-28

Brenes R, Cadena A, Ruiz-Guerrero R (2011) Monitoreo de la concentración de nitrato en el acuífero del Valle de Puebla. Revista Internacional de Contaminación Ambiental 27:313-321

Buczko U, Kuchenbuch RO, Lennartz B (2010) Assessment of the predictive quality of simple indicator approaches for nitrate leaching from agricultural fields. J Environ Manage 91:1305-1315

Burkart M, Stoner J (2008) Nitrogen in groundwater associated with agricultural system. In: Hatfield JL, Follet RF (eds) Nitrogen in the environment: sources, problems, and management. Elsevier Inc, Amsterdam

Calvi, C., Dapeña, C., Martinez, D., Gutheim, F., 2014. Caracterización química e isotópica de la cuenca del arroyo La Ballenera, Partido General Alvarado, provincia de Buenos Aires. Datos preliminares. Venturini et al (Eds), Memorias del II Congreso de Hidrología de Llanuras, Santa Fe, Universidad Nacional del Litoral, 7_100. ISBN 978-987-692-039-1

Calvi, C., Dapeña, C., Massone,H., Martinez, D. 2016a.Características morfométricas y unidades morfodinámicas de mapeo: aplicación al comportamiento hidrológico de una cuenca de llanura. IX Congreso Argentino de Hidrogeología Libro Relación agua superficial - subterránea (Ed. Garcia, R., Rocha Fasola, V. y Dornes, P.) Trab. 6: 229-236. ISBN: 978-987-661-225-8 Ed. UNCA. Catamarca, Argentina, 20 al 23 de septiembre de 2016

Calvi C, Martinez D, Dapeña C, Ghuteim F (2016b) Abundance and distribution of fluoride concentrations in groundwater: $\mathrm{La} \mathrm{Bal}-$ lenera catchment, southeast of Buenos Aires Province, Argentina. Environ Earth Sci. 75:534. https://doi.org/10.1007/s1266 5-015-4972-8

Calvi C, Dapeña C, Martinez D (2018) Present day background of nitrate as a methodology in the surface water-groundwater interaction applied in southeastern Buenos Aires province, Argentina. DYNA 85(207):288-296

CHEM (Chacra Experimental Miramar) Ministerio de Asunto Agrarios de la Provincia de Buenos Aires-Argentina, 2013. http://www. chacramiramar.com.ar/. Accessed 8 Aug 2016

Chowdary VM, Rao NH, Sarma PBS (2005) Decision support framework for assessment of non-point-source pollution of groundwater in large irrigation projects. Agric Water Manag 75:194-225 
Costa JL (1999) Effect of irrigation water quality under supplementary irrigation on soil chemical and physical properties in the "Southern Humid Pampas" of Argentina. J of Crop Production 2(2):85-99

Costa JL, Massone H, Martinez D, Suero EE, Vidal CM, Bedmar F (2002) Nitrate pollution of a rural aquifer and accumulation in the vadose zone. Agric Water Manag 57:33-47

Costa JL, Bedmar F, Daniel P, Aparicio VC (2011). Transporte de Nitratos y Atrazinas en Argiudoles del Sudeste Bonaerense. http:// inta.gob.ar

Cruz JV, Andrade C (2015) Natural background groundwater composition in the Azores archipelago (Portugal): a hydrogeochemical study and threshold value determination. Sci Total Environ 520:127-135

Echeverría HE, Ferrari J (1993) Relevamiento de algunas características de los suelos agrícolas del sudeste de la provincia de Buenos Aires. Boletín Técnico 112. EEA INTA, Balcarce

Edmunds WM, Shand P (2008) Natural groundwater quality. WileyBlackwell, London

ESRI Environment System Research Institute (2012) Página http:// www.esri.com. Accessed 10 July 2016

Fenton O, Richards K, Kirean L, Khalil M, Healy M (2009) Factors affecting nitrate distribution in shallow groundwater under a beef farm in south eastern Irland. J Environ Manage 90:3135-3146

Fewtrell L (2004) Drinking-water nitrate, methemoglobinemia, and global burden of disease: a discussion. Environ Health Perspect 112(14):1371-1374

Follett RF, Hatfield JK (2001) Nitrogen in the environment: sources, problems, and management. Sci World J 1:920-926. https://doi. org/10.1100/tsw.2001.269

Foster S. 1987. Fundamental concepts in aquifer vulnerability pollution risk and protection strategy. Proceedings of International Conference: Vulnerability of Soil and Groundwater to Pollutants. Noordwijk, The Netherlands

Foster S, Hirata R, Gomes D, D’Elia M, Paris M (2002) Protección de la calidad del agua subterránea Guía para empresas de agua, autoridades municipalidades y agencias ambientales. World Bank, Washington

Giuliano Albo J, Blarasin M (2014) Hidrogeoquímica y Estimación del Fondo Natural de nitratos del agua subterránea en un agroecosistema del pedemonte de la Sierra de Comechingones. Revista de la Asociación Geológica Argentina 71(3):378-392

González M 2005. Los ambientes hidrogeológicos de a provincia de Buenos Aires. XVI Congreso Geológico Argentino, Relatorio, Cap XXII, 348-359. La Plata

Hansen B, Sonnenborg TO, Møller I et al (2016) Nitrate vulnerability assessment of aquifers. Environ Earth Sci 75:999. https://doi. org/10.1007/s12665-016-5767-2

Hansen B, Thorling L, Schullehner J et al (2017) Groundwater nitrate response to sustainable nitrogen management. Sci Rep 7:8566. https://doi.org/10.1038/s41598-017-07147-2

Huarte, M. A., Capezio, S.B., 2013. Cultivo de papa. Asignatura cultivo de papa. Unidad Integrada Balcarce Inta FCA UNMdP. http:// inta.gob.ar/documentos/cultivo-depapa/at_multi_download/file/ INTA-\%20huarte_capezio_papa2013.pdf

Hudak PF (2000) Regional trends in nitrate content of Texas groundwater. J Hydrol 228:37-47

INTA (Instituto Nacional de Tecnología Agropecuaria), 1989. Carta de Suelos de la República Argentina (1:50.000). Proyecto PNUDARG 85/019. Secretaría de Agricultura, Ganadería y PescaINTA. Argentina

INTA (Instituto Nacional de Tecnología Agropecuaria) 2011. Cartas de suelo de la República Argentina, Provincia de Buenos Aires. [on-line] http://anterior.inta.gov.ar/suelos/cartas/. Accessed 26 July 2016]
Jordan C, Smith RV (2005) Methods to predict the agricultural contribution to catchment nitrate loads: designation of nitrate vulnerable zones in Northern Ireland. J Hydrol 304(1-4):316-329

Kawagoshi Y, Suenaga Y, Linh Chi N, Hama T, Ito H, Van Duc L (2019) Understanding nitrate contamination based on the relationship between changes in groundwater levels and changes in water quality with precipitation fluctuations, Science of The Total Environment, Volume 657. ISSN 146-153:0048-9697. https://doi. org/10.1016/j.scitotenv.2018.12.041

Kim KH, Yun ST, Kim HK, Kim JW (2015) Determination of natural backgrounds and thresholds of nitrate in South Korean groundwater using model-based statistical approaches. J Geochem Explor 148:196-205

Kruse EE (1986) Aspectos geohidrológicos de la región sudoriental de Tandilla. Cuencas de los Aos. Vivoratá, Las Brusquitas y El Durazno. Asociación Geológica Argentina, Revista XLI 3-4:367-374

L'hirondel J, L'hirondel JL (2001) Nitrate and Man. Toxic, Harmless or Beneficial?. CAB Publishing, Wallingford

Lake IR, Lovett AA, Hiscock KM, Betson M, Foley A, Sünnenberg G (2003) Evaluating factors influencing groundwater vulnerability to nitrate pollution: developing the potential of GIS. J Environ Manag. 68(3):315-328

Lawniczak AE, Zbierska J, Nowak B, Achtenberg K, Grześkowiak A, Kanas K (2016) Impact of agriculture and land use on nitrate contamination in groundwater and running waters in centralwest Poland. Environ Monit Assess 188(3):172. https://doi. org/10.1007/s10661-016-5167-9

Liu A, Ming J, Ankumah RO (2005) Nitrate pollution in private wells in rural Alabama, United States. Sci Total Environ. 346:112-120

Liu F, Song X, Yang L, Han D, Zhang Y, Ma Y, Bu H (2015) The role of anthropogenic and natural factors in shaping the geochemical evolution of groundwater in the Subei Lake basin, Ordos energy base, Northwestern China. Sci Total Environ. 538:327-340

Manassaram DM, Backer LC, Messing R, Fleming LE, Luke B, Monteilh CP. 2010. Nitrates in drinking water and methemoglobin levels in pregnancy: a longitudinal study. Environmental Health 2010, 9:60 http://www.ehjournal.net/content/9/1/60

Martinez, D.E., Osterrieth, M., 2013. Hydrogeochemistry and pollution effects of an aquifer in Quaternary loess like sediments in the landfilling area of Mar del Plata, Argentina Revista Facultad de Ingeniería de la Universidad de Antioquia 66:9-23 (Colombia)

Masetti M, Poli S, Sterlacchini S, Beretta GP, Facchi A (2008) Spatial and statistical assessment of factors influencing nitrate contamination in groundwater. J Environ Manage 8:272-281

Mosciaro, M, Dimuro, V., 2009. Zonas Agroeconómicas homogeneas Buenos Aires Sur. Buenos Aires, INTA. 297 pp. http://inta.gob. ar/documentos/zonas-agroeconomicas-homogeneas-buenos-aires -sur. Accessed 052019

Muñoz H, Armienta A, Vera A, Ceniceros N (2004) Nitrato en el agua subterránea del Valle de Huamantla, Tlaxcala, México. Revista Internacional de Contaminación Ambiental 20:91-97

Óenema O, Boers P, van Eerdt M, Fraters B, van der Meer H, Roest C, Schröder J, Willems W (1998) Leaching of nitrate from agriculture to groundwater: the effect of policies and measures in the Netherlands. Environ Pollut 102:471-478

Panno S, Kelly W, Martinsek A, Hackley K (2006) Estimating background and threshold nitrate concentrations using probability graphs. Ground Water 44:697-709

Picone LI, Andreoli E, Costa JL, Aparicio V, Crespo L, Nannini J, Tambascio W (2003) Evaluación de nitratos y bacterias coliformes en pozos de la Cuenca alta del Arroyo Pantanoso (Buenos Aires). Revista de Investigaciones Agropecuarias. 32(1):99-110

Powlson DS, Addiscott TM, Benjamin N, Cassman KG, de Kok TM, van Grinsven H, L’hirondel JL, Avery AA, Van Kessel C (2008) 
When does nitrate become a risk for humans? J Environ Qual 37:291-295

Qasemi M, Afsharnia M, Farhang M (2018) Health risk assessment of nitrate exposure in groundwater of rural areas of Gonabad and Bajestan. IranEnviron Earth Sci 77:551. https://doi.org/10.1007/ s12665-018-7732-8

Rimski-Korsakov H, Rubio G, Lavado RS (2004) Potential nitrate losses under different agricultural practices in the pampas region, Argentina. Agric Water Manag 65:83-94

Rivett M, Drewes J, Barret M, Chilton J, Appleyard S, Dieter HH, Wauchope D, Fastner J (2006) Chemicals: Health relevance, transport and attenuation. In: Schmoll O, Howard G, Chilton J, Chorus I (eds) Protecting groundwater for health: Managing the quality of drinking water sources, $1^{a}$ edn. LondresSeattle, World Health Organization-IWA

Sala JM (1975). Recursos Hídricos. Relatorio VI Congreso Geológico Argentino, 169-194. Bahía Blanca, Argentina

Sala JM, González N, Kruse EE (1983) Generalización Hidrológica de la Provincia de Buenos Aires. In Coloquio sobre Hidrología de Grandes Llanuras. II, 973-1009. PHI - UNESCO. Olavarría

Suero EE, Santa Cruz JN, Silva Busso A, Della Maggiora A, Irigoyen AJ, Costa JL, Gardiol JM (2002) Caracterización de los Recursos Naturales en sistemas bajo riego del sudeste bonaerense Bases para propuestas de aplicación sustentable del riego. Revista de Investigaciones Agropecuarias, RIA 30(1):71-90

Sutton M, Howard C, Erisman J, Bleeker G, Grennfelt P, Van Grinsven H, Grizzetti B (2011) The European nitrogen assessment sources, effects and policy perspectives. Cambridge University Press, Cambridge
Teruggi M (1954) El mineral volcánico-piroclástico en la sedimentación cuaternaria Argentina. Revista de la Asociación Geológica Argentina IX 3:184-191

Thornthwaite CW (1948) An approach toward a rational classification of climate. Geogr Rev 38(1):55-94

Valujeva K, O’Sullivan L, Gutzler C, Fealy R, Schulte RP (2016) The challenge of managing soil functions at multiple scales: an optimisation study of the synergistic and antagonistic trade-offs between soil functions in Ireland. Land Use Policy 58:335-347

Wheeler DC, Nolan BT, Flory AR, DellaValle CT, Ward MH (2015) Modeling groundwater nitrate concentrations in private wells in Iowa. Sci Total Environ 536:481-488

Wick K, Heumesser C, Schmid E (2012) Groundwater nitrate contamination: factors and indicators. J Environ Manag 111:0301-4797. https://doi.org/10.1016/j.jenvman.2012.06.030

Woli P, Hoogenboom G, Alva A (2016) Simulation of potato yield, nitrate leaching, and profit margins as influenced by irrigation and nitrogen management in different soils and production regions. Agric Water Manag 171:120

World Health Organization (WHO), 2011. Guidelines for Drinkingwater Quality.4th Edition 564 pp ISBN 9789241548151

Publisher's Note Springer Nature remains neutral with regard to jurisdictional claims in published maps and institutional affiliations. 